\title{
Editorials
}

\section{What will be the function of an anesthesiologist in the new millenium?}

$\mathrm{I}$ $\mathrm{N}$ the past few years, the practice of anesthesia has changed considerably. Many factors have influenced these changes. The technology has given the anesthesiologist new tools. By the same token, anesthesia has become much safer and simpler. Examples of such new tools are the pulse oximeter, the capnometer, the agent analyzer. The pulse oximeter has probably done the most to increase the safety of the patient. Instead of relying on skin colour, we now have a fairly precise indicator of the oxygen content of the blood of our patient and we can act faster when there is a deterioration, because of this early warning system. The capnometer has become an indispensable tool. It permits us to verify whether we are ventilating the patient and how well we are doing it. Again, it will tell us very early whether our airway management is adequate and keeps us out of trouble. The agent analyzer has simplified our work. Instead of sometimes using a trial and error technique when maintaining anesthesia, responding when the vital signs are telling us we have made a miscalculation, we can now precisely fine tune our anesthetic regimen.

Other factors have influenced our way of delivering anesthesia services. New pharmacological findings can have revolutionized the delivery of an anesthetic in the last decade. We now have inhalational agents with partition coefficients paralleling those of nitrous oxide. These agents have made our life much simpler. When the surgeon says unexpectedly that he is finished, this is no longer a problem. We can simply close off the vaporizer and emergence is almost instantaneous. A new tool, the laryngeal mask, has revolutionized airway management. Medical students coming to the anesthesia department to learn tracheal intubation, sometimes leave without having honed this skill because we intubate the trachea less and less now. If an intubation is impossible, no problem: we use a laryngeal mask ...
Have other factors changed our work? Medicalisation of surgical procedures has changed the scope of our interventions. Gynecological procedures have diminished in number. We do not even operate on all the ectopic pregnancies, using instead chemotherapy to solve the problem with much less morbidity to the patient. Urological surgery has a narrower niche with the discovery of pharmacological agents that seem to be effective without the use of the scalpel. Major gastroenterological interventions have gone out of style with the advent of more developed endoscopic procedures. We do not talk of general surgery anymore, but about minimally invasive medicine with body cavity minimally invasive surgery. Harvesting of a donor kidney can be undertaken by laparoscopy, colonic tumour resection can be done without an abdominal incision, coronary artery bypass graft can be performed without extra corporeal circulation on a beating heart, the patient coming in the morning and leaving twenty four hours later. Aortic aneurysms are dealt with by intra arterial stents. Obviously, all these novel ways will have an impact on how we are going to practice our profession.

The "virage ambulatoire" not only has changed how we provide anesthesia but has also modified how we evaluate a patient and how we insure that the patient is ready for anesthesia. We can no longer evaluate the patient a day or two before surgery. These patients are now seen weeks before the surgery and, if any optimization is necessary, more and more the anesthesiologist has to do it. The trend is towards the anesthesiologist preparing the patient for his anesthesia and his surgery.

Now that we agree that the practice of anesthesia has radically changed in the last ten to twenty years, what does the new millennium have in reserve for us? The traditional role of the anesthesiologist working in the operating room is probably outdated. Even our

Address correspondence to: Serge Lenis MDCMFRCPC, President, Canadian Anesthesiologists' Society, Department of Anesthesiology, St. Mary's Hospital, Montréal, Québec, H3T 1M5. Phone: 514-345-3511; Fax: 514-734-2600;

E-mail: serge.Lenis@smhc.qc.ca 
involvement in Intensive Care is changing. This area has become a speciality in its own right. The anesthesiologists' new role in the third millennium will be one of perioperative practitioner. We will take care of surgical patients outside the operating room, preparing them for anesthesia and surgery: not the silent anonymous role anymore! During surgery or any other procedures, we will still ensure the safety and well being of our patients. After surgery, we will make sure that they have a comfortable, practically pain free, recovery. Probably, some of the future of anesthesia research will be in analgesia. Slow progress is made in this direction and more is needed. Only a diminishing portion of our patients will be surgical. Our new role will see us taking care of patients who will not have had surgery but who will need our skills to control acute or chronic pain, to permit minimally invasive procedures. We used to be thought of as intensivists, we might be called algologists in the future.

Our traditionnal role was to permit the surgeon to operate. This was done by putting the patient to sleep. The future will pair us with new partners such as endoscopists, invasive radiologists and cardiologists, with the same role of ensuring the security and the comfort of our patients but outside the operating room and using a mix of new techniques in addition to well known ones such as awake sedation or regional block. Because of our knowledge of pharmacology and physiology, we will be asked to monitor patients at risk and intervene without putting them to sleep.

We are part of a society where more and more resources are needed for proper health care delivery. This is happening mainly because of an increase in our aging population which is surviving the common ailments but falling prey to more sophisticated ones. These needed resources are continuously limited by social and political pressures. One of the main "raisons d'être" of a health care centre is the maintenance of an operating room and minimally invasive medicine suites. The anesthesiologists are the only team member with a continuous presence in the operating room and with a thorough knowledge of the other team players' function, so that he will be asked to help in managing these resources, as it is already happening. We are going to find ourselves forced to become managers as well as physicians. Does it mean that the anesthesia training program should include management? Quite possibly! One thing is certain: the anesthesiologist image as the anonymous physician working in the shadow, rarely able to communicate with the patient, has gone. The new millennium anesthesiologist will have to be much more visible, involved in the care of the patient, outside the operating room where he is presently still chained to the work station. The anesthesiologist will have to become a key player in the decision making process concerning health care centres. He will have to be a good communicator, both with the patients and with the other members of the health care delivery system. The old definition of anesthesia: putting a patient to sleep, will not apply anymore. This will be but a small facet of what a third millennium anesthesiologist will be doing.

\section{Quelle sera la fonction de l'anesthésiologiste du nouveau millénaire?}

La pratique de l'anesthésie a beaucoup changé dans les dernières années. De nombreux facteurs ont influencé ces modifications. La technologie a fourni de nouveaux outils aux anesthésiologistes. L'anesthésie est donc devenue plus sécuritaire et plus simple. Parmi les outils nouveaux, on retrouve l'oxymètre de pouls, le capnomètre et l'analyseur d'agents halogénés. C'est sans doute l'oxymètre de pouls qui aura contribué le plus à la sécurité des patients. Plutôt que de se fier à la coloration de la peau, nous pouvons maintenant compter sur un indicateur absolument précis du contenu du sang en oxygène et agir plus rapidement quand la situation se détériore grâce à ce système d'alarme sensible. Quant au capnomètre, il est devenu indispensable. Il permet de vérifier si la ventilation du patient est effective et quelle en est la qualité. De plus, il signale rapidement si l'intubation des voies aériennes est adéquate, nous évitant ainsi des problèmes. L'analyseur d'agents halogénés a simplifié notre travail. Au lieu de procéder par tâtonnements lors du maintien de l'anesthésie, réagissant aux changements des signes vitaux qui indiquent un mauvais calcul, on peut maintenant régler avec précision les régimes anesthésiques.

D'autres facteurs ont influencé notre pratique de l'anesthésie. Pendant la dernière décennie, de nouvelles découvertes pharmacologiques ont révolutionné l'administration d'un anesthésique. Nous utilisons à présent des agents d'inhalation dont les coefficients de partage sont équivalents à ceux du protoxyde d'azote. Ces agents nous ont simplifié la vie. Lorsque le chirurgien termine plus tôt que prévu, ce n'est plus un problème désormais. Nous n'avons qu'à fermer l'évaporateur et le réveil est 
pratiquement instantané. Le nouvel outil qui a transformé la prise en charge des voies aériennes est le masque laryngé. Les étudiants de médecine qui se présentent au département d'anesthésie pour apprendre l'intubation endotrachéale repartent parfois sans avoir eu la chance d'expérimenter cette technique, puisque nous intubons la trachée de moins en moins. Si l'intubation est impossible : nous utilisons le masque laryngé...

D'autres facteurs ont-ils modifié notre tâche? La médicalisation des interventions chirurgicales a changé notre champ d'action. Les interventions gynécologiques sont moins nombreuses. Nous n'opérons plus dans tous les cas de grossesse ectopique, nous utilisons plutôt la chimiothérapie pour résoudre le problème tout en réduisant la morbidité. La chirurgie urologique occupe une plus petite part depuis la découverte des agents pharmacologiques qui se révèlent efficaces sans scalpel. Les interventions gastro-entérologiques majeures ne sont plus à la mode avec l'avènement d'un plus grand nombre d'interventions endoscopiques élaborées. Nous ne parlons plus de chirurgie générale, mais de médecine à effraction minimale avec l'arrivée de la chirurgie à incision minimale. On peut prélever le rein d'un donneur sous laparoscopie, procéder à la résection d'une tumeur colique sans incision abdominale, réaliser un pontage aortocoronarien à coeur battant et sans circulation extracorporelle, le patient se présentant le matin et quittant l'hôpital vingt-quatre heures plus tard. Les anévrismes aortiques sont traités avec des tuteurs intra-artériels. De toute évidence, toutes ces innovations ont un impact sur la façon dont nous allons exercer notre profession.

Le virage ambulatoire a non seulement changé la manière d'administrer l'anesthésie, mais a aussi modifié l'évaluation du patient et la préparation de ce dernier à recevoir l'anesthésie. Nous n'avons plus à rencontrer le patient un jour ou deux avant l'opération. L'examen peut avoir lieu des semaines avant l'opération et, si quelque amélioration de la condition préopératoire est nécessaire, il revient de plus en plus à l'anesthésiologiste de s'en occuper. L'orientation actuelle veut que les anesthésiologistes préparent le patient à l'anesthésie et à la chirurgie.

Maintenant que nous sommes d'accord pour dire que l'exercice de l'anesthésie a radicalement changé dans les dix à vingt dernières années, que pouvons-nous attendre du nouveau millénaire? Le rôle traditionnel de l'anesthésiologiste qui travaille dans la salle d'opération est probablement dépassé. Même notre participation aux soins intensifs s'est modifiée. Ce domaine est devenu une spécialité en elle-même. Au troisième millénaire, le nouveau rôle des anesthésiologistes sera un rôle de praticien périopératoire. Nous traiterons des patients chirurgicaux en dehors de la salle d'opération, les préparant à l'anesthésie et à l'intervention chirurgicale : fini le rôle anonyme et silencieux! Pendant l'opération ou toute autre intervention, nous assurerons encore la sécurité et le bien-être de nos patients. Après l'opération, nous veillerons à ce qu'ils bénéficient d'une récupération pratiquement sans douleur. Une partie de la recherche future en anesthésie concernera probablement l'analgésie. Les progrès sont lents dans ce domaine et les besoins sont encore grands. Seul un nombre décroissant de nos patients relèvera de la chirurgie. Notre nouveau rôle nous amènera à nous occuper de patients qui n'auront pas eu d'opération, mais qui auront besoin de nos connaissances pour contrôler la douleur aiguë ou chronique, pour permettre des interventions à effraction minimale. On nous voyait comme des intensivistes; à l'avenir, on sera peut-être algologistes.

Notre rôle traditionnel était de permettre au chirurgien d'opérer. Ce que nous avons réalisé en anesthésiant le patient. L'avenir nous réunira à de nouveaux partenaires, comme les endoscopistes, les radiologistes et les cardiologues qui utilisent des techniques effractives; nous assurerons toujours la sécurité et le confort des patients, mais à l'extérieur de la salle d'opération et selon une combinaison de nouvelles techniques qui s'ajouteront à des plus connues comme la sédation vigile et l'anesthésie régionale. Étant donné nos connaissances de la pharmacologie et de la physiologie, nous devrons surveiller des patients à risque et intervenir sans anesthésie profonde.

Nous faisons partie d'une société où de plus en plus de ressources sont nécessaires aux soins de santé adaptés. Cela survient principalement parce que le nombre de personnes âgées augmente, lesquelles survivent aux affections communes, mais succomberont à des maladies plus complexes. Ces ressources nécessaires sont continuellement limitées par des pressions politiques et sociales. L'une des principales raisons d'être d'un centre de soins de santé est le maintien d'une salle d'opération et des services médicaux à effraction minimale. Les anesthésiologistes sont les seuls membres de l'équipe toujours présents dans la salle d'opération. Ils ont une connaissance approfondie des fonctions des autres membres de sorte qu'ils seront appelés à gérer ces ressources comme cela se produit déjà. Nous allons nous retrouver obligés d'être gestionnaires autant que médecins. Le programme d'anesthésie devra-t-il comporter une formation en gestion? C'est fort possible! Une chose est sûre : l'image de l'anesthésiologiste, présenté comme le médecin anonyme qui travaille dans l'ombre, et qui ne peut que rarement communiquer avec le patient, n'est plus. L'anesthésiologiste du nou- 
veau millénaire devra être beaucoup plus visible, engagé auprès du patient, à l'extérieur de la salle d'opération où est présentement encore confiné son poste de travail. L'anesthésiologiste deviendra un acteur important dans la prise de décisions qui concernent les centres de santé. Il devra être un bon communicateur, autant avec le patient qu'avec les autres membres du système de soins de santé. L'ancienne définition de l'anesthésie : endormir un patient, ne s'appliquera plus dorénavant. Ce ne sera plus qu'une facette du travail de l'anesthésiologiste du troisième millénaire. 